\title{
Különbségek a Fontan-, illetve TCPC-mútéten átesett felnőtt populációnk hosszú távú kimenetelében
}

\author{
Pataki Szabina, Sárkány Beatrix, Szegedi Margit, Takács Edit, Fischer Szilvia, \\ Környei László, Ablonczy László, Andréka Péter, Temesvári András, \\ Bálint Olga Hajnalka
}

Gottsegen György Kardiologiai Intézet, 1096 Budapest, Haller utca 29.

Levelezési cím:

Dr. Pataki Szabina, 1096 Budapest, Haller utca 29. E-mail: pataki.szabina@kardio.hu

\begin{abstract}
Bevezetés: Az univentrikuláris szív palliatív mütétje a jobb pitvar-pulmonalis artéria anasztomózissal (RA-PA) járó Fontan, valamint a korszerübb, konduit segítségével kialakított teljes cavo-pulmonalis kapcsolat (TCPC). A mütét következménye a non-pulzatilis vénás keringés, amely hosszú távon a Fontan-/TCPC-keringés elégtelenségéhez (Fontan-failure) vezethet, szívtranszplantáció (HTX) indikációját képezve.

Célkitűzés: Fontan/TCPC-műtéten átesett felnőtt betegek hosszú távú szövődményeinek elemzése, összehasonlítva a Fontant a TCPC-s populációval.

Betegek és módszerek: Vizsgálatunkba 2001-2017 között Intézetünkben kezelt és felnőttként legalább 1 évig követett Fontan/ TCPC-s beteget vontunk be, valamint rögzítettük az utánkövetés során észlelt eseményeket.

Eredmények: 73 Fontan/TCPC-s beteget vizsgáltunk (Fontan: n=18, TCPC: $n=55$ ). A korszerübb TCPC-típusú mütétre fiatalabb korban került sor a klasszikus Fontan-mütéttel összevetve $(7,4 \pm 6,9$ vs. $12,3 \pm 7,0$ év, p<0,05). A mütéttöl eltelt átlagos utánkövetési idő $17,8 \pm 3,8$ év

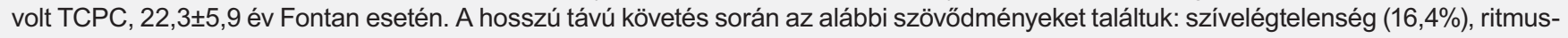
zavar (32,8\%), tromboembóliás esemény (15,1\%), cirrózis (21,9\%), és fehérjevesztő enteropathia (5,4\%). A TCPC-betegekhez hasonlítva, Fontan esetén a pitvari ritmuszavar $(p=0,005)$ és a hospitalizációt igénylő szívelégtelenség $(p=0,026)$ volt gyakoribb. Fontan keringési elégtelenség a betegek 16,4\%-ban jelentkezett, ez a Fontanosok 22,2\%-át, illetve a TCPC-sek 14,5\%-át jelenti ( $p=0,44)$. A mortalitás 5,4\% volt, két betegnél HTX történt; ez utóbbi eseményekben nem volt különbség a Fontan- és a TCPC-betegek arányában.

Következtetések: A Fontan/TCPC magas morbiditású fiatal populáció. A Fontan-típusú mütét csak a pitvari ritmuszavarok és a hospitalizációt igénylő szívelégtelenség megjelenése szempontjából bizonyult kockázatosabbnak. A Fontan-failure szempontjából meghatározó tényezőnek a betegek életkora bizonyult a komplettálás idején.
\end{abstract}

Kulcsszavak: egykamrás keringés, Fontan-mútét, teljes cavo-pulmonalis kapcsolat (TCPC), Fontan-elégtelenség

Differences between Fontan and TCPC procedures based on adult patients' long-term outcome

Background: The Fontan surgery is a palliative procedure in patients with univentricular heart performed as the classic right atrial to pulmonary connection (RA-PA), or total cavopulmonary connection (TCPC). The non-pulsatile venosus circulation leads to the insufficiency of the venous circulation, known as Failing Fontan. This condition represents an indication for heart transplantation (HTX).

Aims: To evaluate the long-term outcomes of adult patients after Fontan/TCPC procedure, and compare the clinical outcomes of Fontan and TCPC populations.

Methods: Patients were enrolled who underwent Fontan/TCPC operation between 2001-2017 at our Institute with a follow-up at least 1 year and complications were assessed.

Results: 73 Fontan/TCPC patients were enrolled in our study (Fontan: $n=18$, TCPC: $n=55$ ). TCPC was carried out in substantially younger patients as compared to traditional Fontan procedure ( $7.4 \pm 6.9$ vs. $12.3 \pm 7.0$ years; $p<0.05)$. The mean follow-up time was 22.3 \pm 5.9 years after Fontan, and 17.8 \pm 3.8 years after TCPC surgery. The following complications were registered during follow-up: $16,4 \%$ had heart failure, $32.8 \%$ had arrhythmias, $15.1 \%$ thromboembolic events, $21.9 \%$ had liver cirrhosis and $5.4 \%$ had protein-losing enteropathy. Compared with TCPC, Fontan patients presented with a higher rate of atrial arrhythmia $(p=0.005)$ and hospitalization for heart failure $(p=0.026)$. Failing Fontan was observed in $16.4 \%$ of patients (Fontan: $22.2 \%$, TCPC 14.5\%; $p=0.44$ ). During the study period 4 patients died, and 2 were transplanted (no difference was found in regard to these events and type of surgery). Conclusion: Despite of younger age, patients with Fontan/TCPC operation are at high risk for morbidities. The Fontan surgery when compared with TCPC seems to carry a higher risk for atrial arrhythmias and heart failure requiring hospitalization. The patient's age at operation was a predictor of Failing Fontan.

Keywords: univentricular heart, Fontan procedure, total cavopulmonary connection (TCPC), Fontan failure 


\section{Bevezetés}

A komplex víciumok egykamrás keringési modelljének kialakitására Fontan francia sebész egyedi műtéti típust hozott létre 1968-ban (1, 2). A műtét többlépcsős, a befejező műtét alapján több típusát különíthetjük el: a klasszikus, korai Fontan-mütétek esetén a jobb pitvar segítségével terelték a cavák vérét a pulmonalis artériákba (RA-PA), míg TCPC során ez intrakardiális (laterális) tunnel vagy extrakardiális konduit segítségével történik (3). A Fontan-keringés sajátossága, hogy nincs szubpulmonalis kamra, ezáltal egy non-pulzatilis vénás keringés alakul ki, amely pulmonalis vaszkuláris rezisztencia- (PVR) függő, így csak alacsony PVR mellett müködik. Mivel a kamra telődése előterhelés-függő, és a non-pulzatilis áramlás miatt az elöterhelés csökkent, így alacsony verővolumennel számolhatunk. Mindezek a Fontan keringési elégtelenség, az úgynevezett Fontan-failure kialakulásához vezetnek (4).

A Fontan keringési elégtelenség két formája ismert, bár a tünetek és a háttérben álló mechanizmusok gyakran keverednek (5). A csökkent kamrafunkcióval járó Fontan-elégtelenség kamradiszfunkció talaján alakulhat $\mathrm{ki}$, az atrioventrikuláris (AV) billentyű regurgitációjával vagy anélkül. Ennek a formának a jellemzője az alacsony perctérfogat-szindróma, valamint a csökkent terhelhetőség (6). A megtartott kamrafunkcióval járó Fontan-failure esetén hemodinamikailag jelentős szükület vagy pulmonalis vaszkuláris betegség kóroki szerepe merül fel. Ennek következtében magas Fontan-nyomások alakulnak ki, súlyos vénás hipertónia jelenik meg. Ez az állapot pleurális folyadék és ascites megjelenéséhez vezethet, vagy fehérjevesztő enteropathia, valamint plasztikus bronchitis kialakulását okozhatja, mindazonáltal kedvez a protrombotikus folyamatoknak (7-9). A társuló egyéb problémák, mint ritmuszavar, máj- és veseelégtelenség is gyakoriak. A májelégtelenség kialakulása a gyermekkortól (a komplettálástól) folyamatosan lehetséges a normálisnál magasabb centrális vénás nyomás következtében $(6,10)$. Cianózis a fenesztrált formákat jellemzi, illetve a pulmonalis arterio-venosus fisztulák esetén észlelhető (11).

Jelenleg még limitált információ áll rendelkezésre a hagyományos Fontan- és a korszerübb TCPC-mütéten átesett betegek hosszú távú eredményeiről $(12,8)$.

Célkitüzésünk volt a Fontan-/TCPC-mütéten átesett felnőtt betegeink hosszú távú szövődményeinek elem- zése, összehasonlítva a klasszikus Fontan-mütéten átesett betegeket a TCPC-s populációval.

\section{Betegek és módszerek}

A vizsgálatba 2001-2017 között Intézetünkben kezelt és felnőttként legalább egy évig követett Fontan/ TCPC-s beteget vontunk be, valamint dokumentáltuk az utánkövetés során észlelt eseményeket (1. táblázat). A Gottsegen György Országos Kardiológiai Intézetben felnőtt veleszületett szívbetegség (GUCH) ambulancián követett Fontan/TCPC-s betegek retrospektív vizsgálata történt. Adatbázisba rögzítettük a demográfiai adatokat, mütéti leírásokat, valamint a követés során észlelt kardiovaszkuláris eseményeket (ritmuszavar, szívelégtelenség, stroke, más tromboembóliás esemény, fehérjevesztő enteropathia, cianózis, intervenciók, májelégtelenség), illetve az utolsó ambuláns vizsgálat föbb eredményeit (funkcionális állapot, laborvizsgálatok, echokardiográfia vizsgálat). Fontan keringési elégtelenségként definiáltuk a kezelést igénylő vénás keringési elégtelenséget (ödéma, ascites, fehérjevesztő enteropathia). A kamrafunkció, illetve víciumok megítélése szemikvantitatív meghatározással történt két tapasztalt echokardiográfus által. Májelégtelenséget, cirrózist az emelkedett enzimértékek alapján definiáltuk (laborvizsgálat), bizonyos esetekben kiegészítve hasi ultrahang, fibroscan, májbiopszia-vizsgálatokkal.

A Fontan- és TCPC-csoport adatait folytonos paramé-

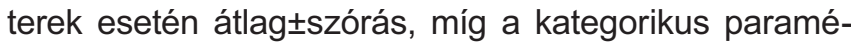
terek esetén darabszámként tüntettük fel. A csoportok közti különbségek számításánál a folytonos paraméterek esetén nem parametrikus Mann-Whitney-tesztet, míg kategorikus változók esetén Chi-négyzet próbát alkalmaztunk. A túlélés és adverz események időbeli eloszlását Kaplan-Meier-görbén ábrázoltuk és Log-rank teszt segítségével vetettük össze a két csoportban. Univariáns logisztikus regressziós analízist végeztünk a failing Fontan lehetséges prediktorainak meghatározására.

\section{Eredmények}

A felnőttkort megélt betegpopulációnk 73 főböl áll (Fontan-csoport: 18 beteg, TCPC: 55 beteg), átlagéletkoruk 27 év, a férfiak aránya $63 \%$ volt. A mütétet indikáló kór-

1. TÁBLÁZAT. Az utánkövetés során dokumentált események, illetve előfordulásuk a két csoportban

\begin{tabular}{|c|c|c|c|c|}
\hline & Összes esemény & Fontan & TCPC & $p=0,23$ \\
\hline Fontan-failure & $12(16,4 \%)$ & $4(22,2 \%)$ & $8(14,5 \%)$ & 0,44 \\
\hline Szívelégtelenség & $12(16,4 \%)$ & $6(33,3 \%)$ & $6(10,9 \%)$ & 0,026 \\
\hline Ritmuszavar & $24(32,8 \%)$ & $12(66,7 \%)$ & $12(21,8 \%)$ & $<0,005$ \\
\hline Cirrózis & $16(21,9 \%)$ & $2(11,1 \%)$ & $14(25,5 \%)$ & 0,20 \\
\hline Fehérjevesztő enteropathia & $4(5,4 \%)$ & $1(5,6 \%)$ & $3(5,5 \%)$ & 0,401 \\
\hline Tromboembólia & $14(19,2 \%)$ & $6(33,3 \%)$ & $8(14,5 \%)$ & 0,079 \\
\hline
\end{tabular}




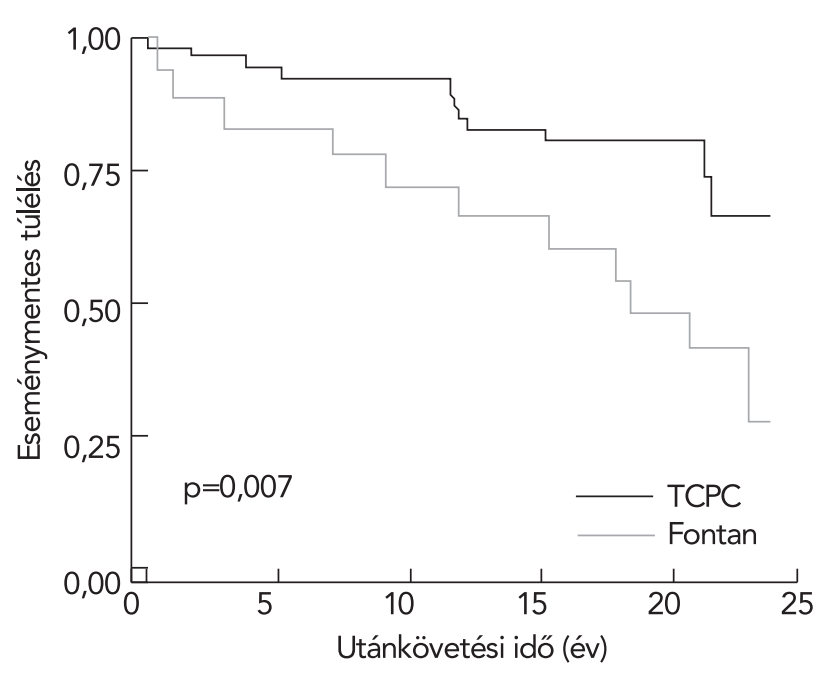

1. ÁBRA. Ritmuszavarok megjelenése az utánkövetés során. A Fontan-betegeknél szignifikánsan magasabb arányban detektáltunk ritmuszavart a TCPC-betegekhez képest

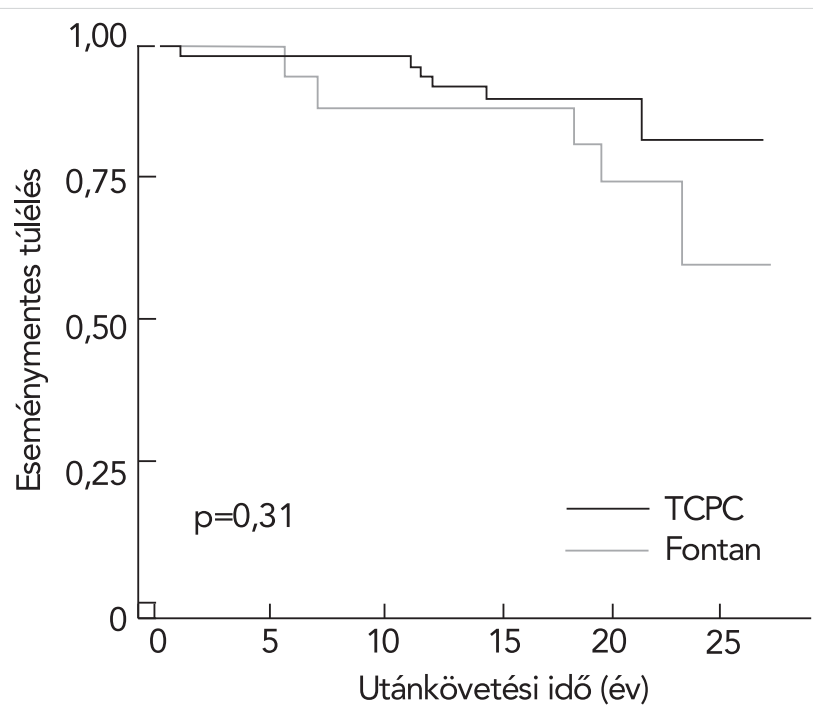

2. ÁBRA. Szívelégtelenség miatti hospitalizáció alakulása a Fontan- és TCPC-betegekben

ok a legtöbb esetben tricuspidalis atrézia volt (29), ezt követte a hipopláziás jobb kamra (10), a kettős kiáramlású jobb kamra (8), a kettős beáramlású bal kamra (5), valamint a nem determinált univentrikuláris szív (21). Csökkent tüdőkeringéssel járó víciumok esetén első lépcsőben, előkészítő mủtétként sönt kialakítása történt (72,6\%). 18 beteg klasszikus Fontan-operáción esett át, míg 55 betegnél TCPC kialakítása történt lateralis tunnel $(n=19)$ vagy extrakardiális konduit $(n=36)$ segítségével. 27 esetben fenesztrációra volt szükség. A fenesztrációk egy része később zárásra került (44,4\%). $A z$ átlagéletkor a mütét (komplettálás) idején 12,3 $\pm 7,0$

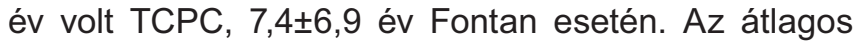
utánkövetési idő mútét után $17,8 \pm 3,8$ év volt a TCPC és 22,3 $\pm 5,9$ év a Fontan-betegcsoportban.
Ritmuszavart 24 esetben detektáltunk, ebből pitvari tachycardia 11, pitvari flutter 5, pitvarfibrilláció 6 , WPW-szindróma 1, illetve kamrai tachycardia 1 betegnél jelentkezett. Ablációt 8 esetben végeztünk. Sick sinus szindróma miatt két esetben történt epikardiális pacemaker-implantáció. A Fontan-csoportban magasabb pitvari aritmia arányt észleltünk (Fontan: $66,4 \%$ versus TCPC: 21,8\%; p<0,005) (1. ábra).

Csökkent kamrafunkciót találtunk a Fontan-betegek 38,9\%-ánál, a kamradiszfunkció aránya a TCPC-betegek körében $36,4 \%$ volt. 51 esetben találtunk legalább enyhe fokú víciumot (69,8\%).

A szívelégtelenség időben korábbi megjelenése detektálható a Fontan-csoportban. A hospitalizációt igénylő szívelégtelenség gyakorisága is nagyobb a klasszikus csoportban, amely a két csoport között szignifikáns, Fontan: 6 (33,3\%), TCPC: 6 (10,9\%), p=0,026 (2. ábra). Fontan keringési elégtelenség a betegek 16,4\%-ában jelent meg, ez klasszikus Fontan után 22,2\%-ban, TCPC után a betegek 14,5\%-ában észleltük, a különbség ugyan nem volt szignifikáns $(p=0,44)$. Univariáns analízis alapján a Fontan keringési elégtelenség kialakulásának legmeghatározóbb prediktora a betegek életkora volt a komplettálás idején ( $p=0,011$; rizikóhányados: 1,110).

Két betegnél került sor Fontan-failure miatt szívtranszplantációra; mindkettő klasszikus Fontan-mútéten esett át korábban, egyik esetben a csökkent kamrafunkció állt a Fontan keringési elégtelenség hátterében, a másik esetben a szisztémás kamradiszfunkciója mellett fehérjevesztő enteropathia tünetei is jelentkeztek („kevert típusú" Fontan-failure).

A tromboembóliás szövődmény előfordulása Fontan esetén $33,3 \%$, TCPC esetén $14,5 \%$ volt. A hasonló antikoagulációs irányelvek ellenére klasszikus Fontan esetén a tromboembóliás események gyakoribb előfordulása volt igazolható $(p=0,079)$.

A cirrózis kialakulása a klasszikus csoportban 11,1\%ban, TCPC esetén 25,5\%-ban volt észlelhető $(p=0,20)$. $\mathrm{Az}$ emelkedett májfunkciós paraméterek és a cirrózis előfordulása a két csoportban nem különbözött $(p=0,63$; illetve $p=0,20)$.

Az utolsó ambuláns vizit alapján a gyógyszeres terápiát illetően antikoaguláns kezelést 88,2\%-ban, antitrombotikus terápiát 11,8\%-ban, béta-blokkoló kezelést 37,0\%ban, míg angiotenzinreceptort gátló (ACEi) kezelést 49,1\%-ban alkalmaztunk. Fehérjevesztő enteropathia miatt tartós szteroid- (budenozid) kezelés két esetben történt, valamint pulmonalis hipertónia specifikus kezelésben aktuálisan szintén két beteg részesült.

A túlélési adatok a felnőttkort megélt betegekre vonatkoznak, a teljes mortalitás $5,4 \%$ volt a vizsgált periódusban. A mortalitási adat a gyermekkorban elvesztett betegek adatainak hiányában korlátozottan értékelhető. A leggyakoribb halálok a Fontan-failure volt. Mind a ritmuszavar, mind a keringési elégtelenség magasabb tendenciája okozza a Kaplan-Meier-görbén látható 


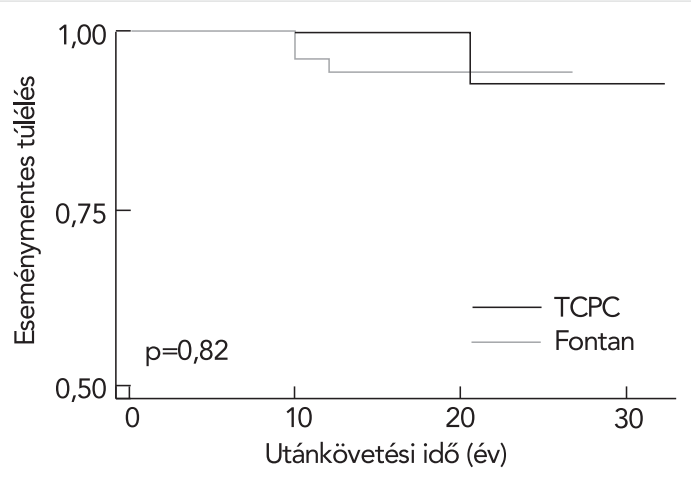

3. ÁBRA. Mortalitás a Fontan- és TCPC-betegpopulációban

jobb eseménymentes túlélési adatokat TCPC esetén (3. ábra).

A vizsgált végpontokat illetően az utánkövetési időszakban 15 betegnél eseményt nem detektáltunk, ez Fontan esetén 2, TCPC esetén 13 beteg volt.

\section{Megbeszélés}

Fiatal populációnkban közel két évtizeddel a Fontan/ TCPC-mütét után jelentős morbiditási tényezőként jelentkezik az egykamrás keringési elégtelenség, amely a betegek 16\%-ában fordul elő. A hosszú távú komplikációk többnyire a klasszikus Fontan-mütéthez köthetőek. A komplettálás kitolódása magasabb életkorra ( $>7$ év) a nemzetközi tapasztalatokkal egyezően növelte a késői szövődmények számát (13). A Fontan-csoportban relatíve magasabb életkorban került sor a mütétre, ezzel magyarázható ebben a betegcsoportban a túlélés szempontjából meghatározó, jelen közleményben vizsgált végpontok magasabb aránya. Manapság általános elv, hogy a korrekciós, valamint a palliaciós mútétek kora csecsemőkorban megtörténjenek.

A pumpa nélküli pulmonalis keringés magában hordozza a keringési elégtelenség kialakulását. A csökkent bal kamrai előterhelés, a szisztémás kamra gyakori diszfunkciója, a tartós vénás pangás nemcsak alacsony perctérfogat szindrómát eredményez, de szekunder szervi elégtelenségek kialakulása is kódolva van. A túlélés szempontjából az egyik leginkább meghatározó tényező a Fontan-asszociált májelégtelenség megjelenése, mely idővel cirrózisba progrediál, átlagosan a betegek 21\%-ában észlelhető $(14,15)$. A magas vénás nyomás, amely a Fontan-keringés (pulmonalis keringés) fenntartásához szükséges, mellkasi folyadékgyülemek, ascites, illetve a bélrendszer érintettségeként kialakult fehérjevesztő enteropathia kifejlődésében is meghatározó fontosságú, utóbbi előfordulása ebben a betegcsoportban 5-15\% közé tehető $(16,17)$.

Az egykamrás víciumok esetén kialakult keringési elégtelenség (Fontan-failure) jelentős kihívást jelent a kezelés szempontjából. A Fontan-elégtelenség sem patomechanizmusában, sem szövődményeiben, sem terápiájában nem hasonlítható a kétkamrás keringés mellett létrejött „klasszikus” keringési elégtelenséghez (18). Nemzetközi vizsgálatok átlagos 8 éves utánkövetése során a krónikus vénés keringési elégtelenség, Fontan-failure az esetek 22\%-ában jelent meg, amelynek prevalenciája kétszer magasabb az átlagpopulációhoz képest (19).

Kísérőbetegségként, a lassult vénás keringés miatt, különösen klasszikus Fontan esetén, tromboembóliás szövődmények alakulnak ki a jobb oldalon (20), ezek gyakorisága 20\% körüli (21). Az antitrombotikus versus antikoaguláns terápia „haszna”, illetve prioritása a hazai populációban sem eldöntött, a Fontan-csoportban gyakoribb volt az antikoaguláns kezelés (22). Klaszszikus Fontan esetén ehhez még a jobb pitvar mútéti hegek, illetve a jobb pitvar feszülése miatt a szupraventrikuláris ritmuszavarok társulnak jelentős számban (75\%) (23). Nemzetközi vizsgálatok alapján a leggyakrabban dokumentált komplikáció az aritmiák megjelenése volt, ezek incidenciája 3-41\% között alakult (8), a klasszikus Fontan-csoportban ez az arány elérte az $50-60 \%$-ot is (24). Béta-blokkoló primer alkalmazása nem indokolt (megerősítő adat nincs), elsősorban társuló ritmuszavarokban került alkalmazásra. A keringési elégtelenségben rutinszerüen alkalmazott ACE-gátlók hatékonysága sokkal kevésbé effektív, a kezelés „preventív” szerepe is megkérdőjelezhető, azonban a keringési elégtelenség kialakulása után, elsősorban kamradiszfunkció esetén a betegek döntő része kapott ACEi-terápiát (25). Pulmonalis hipertónia specifikus kezelés, magas pulmonalis vaszkuláris rezisztencia esetén, leggyakrabban megtartott kamrafunkcióval járó Fontan-failure mellett jön szóba $(26,27)$. A gyógyszeres terápia alkalmazása a nemzetközi tapasztalatoknak megfelelt, de elmondható, hogy korlátozott lehetőségek állnak rendelkezésre ezen betegek hosszú távú kezelésében.

Amennyiben Fontan-failure hátterében javítható hemodinamikai ok nem igazolható (konduit szűkület, pulmonalis artéria szükület, szisztémás AV-billentyű regurgitáció), szívtranszplantáció jön szóba (28). Mivel a keringési elégtelenség kialakulásának dinamikája sokkal lassabb, mint kétkamrás elégtelenség esetén, a sürgősségi transzplantációs státuszt ezek a betegek nem érik el. Ez a világszerte meglévő donorhiány mellett igen nehéz szívtranszplantációs lehetőséget jelent. Mindazonáltal a donor szervhez történő hozzáférés is nehezebb ebben a betegcsoportban, de a társuló hepatopathia, a többszöri mútétek következtében gyakori hiperimmunizáció, a rekontstruálandó pulmonalis artériák és cavák, a gyakori pulmonalis AV-fisztulák miatt a transzplantációs mortalitás is sokkal magasabb (29). Az átlagpopulációban a szívtranszplantáció utáni 1 éves túlélés 84,5\% (30). Irodalmi adatok alapján szívtranszplantáció átlagosan 3,5\%-ban történt a vizsgált populációban (31). 
A Fontan-típusú műtét a pitvari ritmuszavarok és a hospitalizációt igénylő keringési elégtelenség szempontjából bizonyult kockázatosabbnak. A korai, klasszikus Fontan-mútéten átesett és a TCPC megoldással operált betegcsoportokat összehasonlítva nem találtunk szignifikáns különbséget a cirrózis, a tromboembóliás események, valamint a halálozás esetében a két csoportban. Az elmúlt években a mútéti technika fejlődésének köszönhetően a túlélés jelentősen javult (32), a legújabb eredmények alapján a mortalitás 20\%-ról 0,5\%-ra csökkent. A késői halálozásban meghatározó szerepe volt a kamradiszfunkciónak, a Fontan keringési elégtelenségnek, valamint a Fontan-failure mellett megjelenő magas pulmonalis vaszkuláris rezisztenciának $(4,18)$. Vizsgálatunkban nem detektáltunk szignifikáns különbséget a Fontan- és TCPC-betegcsoport között, habár eredményeinket befolyásolhatja a vizsgált betegpopuláció mérete és a keményvégpont (mortalitás) alacsony aránya, amelyek vizsgálatunk fő limitációi. A betegek további nyomonkövetése szükséges a különböző hemodinamikával járó két csoport morbiditási adatainak szignifikáns kialakulásához (89).

\section{Következtetések}

A Fontan/TCPC magas morbiditású fiatal populáció, amelyben a korai optimális mütét, a szoros gondozás, a társuló szövődmények korai felismerése és kezelése, valamint a szívtranszplantációs várólistára helyezés optimális időzítése jelenthet nagyobb sikerarányt ezen betegcsoport hosszú távú kezelésében.

\section{Irodalom}

1. Ono M, Boethig D, Goerler H, Lange M, Westhoff-Bleck M, Breymann T. Clinical outcome of patients 20 years after Fontan operation - effect of fenestration on late morbidity. Eur J Cardiothorac Surg 2006; 30: 923929. doi: 10.1016/j.ejcts.2006.08.025

2. Dubourg G, Fontan F, Blanchot $P$, Dallochio $M$, Bricaud $H$, Broustet $P$ [Tricuspid atresia \& its surgical treatment]. J Med Bord 1959; 136: 699-712. 3. Ninan M, Myers JL. Conversion of the atriopulmonary Fontan connection to a total cavopulmonary connection. Semin Thorac Cardiovasc Surg Pediatr Card Surg Annu 1998; 1: 2330. doi: 10.1016/S1092-9126(98)70007-9 4. Gewillig M. The Fontan circulation. Heart 2005; 91: 839-846. doi: 10.1136/hrt.2004.051789

5. Griffiths ER, Kaza AK, Wyler von Ballmoos MC, et al. Evaluating failing Fontans for heart transplantation: predictors of death. Ann Thorac Surg 2009; 88: 558-563. Discussion 563-554. doi: 10.1016/j.athoracsur.2009.03.085

6. Gewillig M, Goldberg DJ. Failure of the fontan circulation. Heart Fail Clin 2014; 10: 105-116. doi: 10.1016/j.hfc.2013.09.010

7. Aboulhosn J, Williams R, Shivkumar K, et al. Arrhythmia recurrence in adult patients with single ventricle physiology following surgical Fontan conversion. Congenit Heart Dis 2010; 5: 430-434. doi: 10.1111/j.17470803.2010.00443.x

8. Kverneland LS, Kramer P, Ovroutski S. Five decades of the Fontan operation: A systematic review of international reports on outcomes after univentricular palliation. Congenit Heart Dis 2018; 13: 181-193. doi: 10.1111/chd.12570

9. Chopra PS, Rao PS. Surgical management of congenital heart defects: current trends. Indian J Pediatr 1991; 58: 623-640. doi: 10.1007/ BF02820180

10. Ono M, Kasnar-Samprec J, Hager A, et al. Clinical outcome following total cavopulmonary connection: a 20-year single-centre experience. Eur J Cardiothorac Surg 2016; 50: 632-641. doi: 10.1093/ejcts/ezw091

11. Deal BJ, Jacobs ML. Management of the failing Fontan circulation. Heart 2012; 98: 1098-1104. doi: 10.1136/heartjnl-2011-301133

12. de Leval MR, Kilner P, Gewillig M, Bull C. Total cavopulmonary connection: a logical alternative to atriopulmonary connection for complex Fontan operations. Experimental studies and early clinical experience. J Thorac Cardiovasc Surg 1988; 96: 682-695.

13. Hosein RB, Clarke AJ, McGuirk SP, et al. Factors influencing early and late outcome following the Fontan procedure in the current era. The 'Two Commandments'? Eur J Cardiothorac Surg 2007; 31: 344-352. Discussion 353. doi: 10.1016/j.ejcts.2006.11.043

14. Pundi K, Pundi KN, Kamath PS, et al. Liver Disease in Patients After the Fontan Operation. Am J Cardiol 2016; 117: 456-460. doi: 10.1016/j. amjcard.2015.11.014

15. Daniels CJ, Bradley EA, Landzberg MJ, et al. Fontan-Associated Liver Disease: Proceedings from the American College of Cardiology Stakeholders Meeting, October 1 to 2, 2015, Washington DC. J Am Coll Cardiol 2017; 70: 3173-3194. doi: 10.1016/j.jacc.2017.10.045

16. Mertens L, Hagler DJ, Sauer U, Somerville J, Gewillig M. Protein-losing enteropathy after the Fontan operation: an international multicenter study. PLE study group. J Thorac Cardiovasc Surg 1998; 115: 1063-1073. doi: 10.1016/S0022-5223(98)70406-4

17. Rychik J. Protein-losing enteropathy after Fontan operation. Congenit Heart Dis 2007; 2: 288-300. doi: 10.1111/j.1747-0803.2007.00116.x 18. Kotani $Y$, Chetan D, Zhu J, et al. Fontan Failure and Death in Contemporary Fontan Circulation: Analysis From the Last Two Decades. Ann Thorac Surg 2018; 105: 1240-1247. doi: 10.1016/j.athoracsur.2017.10.047 19. Alsaied T, Bokma JP, Engel ME, et al. Factors associated with longterm mortality after Fontan procedures: a systematic review. Heart 2017; 103: 104-110. doi: 10.1136/heartinl-2016-310108

20. McCrindle BW, Manlhiot C, Cochrane A, et al. Factors associated with thrombotic complications after the Fontan procedure: a secondary analysis of a multicenter, randomized trial of primary thromboprophylaxis for 2 years after the Fontan procedure. J Am Coll Cardiol 2013; 61 : 346-353. doi: 10.1016/j.jacc.2012.08.1023

21. Yang H, Bouma BJ, Mulder BJM. Non vitamin KaOafTpiachdi Is Initiating NOACs for Atrial Arrhythmias Safe in Adults with Congenital Heart Disease? Cardiovasc Drugs Ther 2017; 31: 413-417. doi: 10.1007 s10557-017-6745-y

22. Walker HA, Gatzoulis MA. Prophylactic anticoagulation following the Fontan operation. Heart 2005; 91: 854-856. doi: 10.1136/ hrt.2004.039073

23. Deal BJ, Mavroudis C, Backer CL. Arrhythmia management in the Fontan patient. Pediatr Cardiol 2007; 28: 448-456. doi: 10.1007/s00246007-9005-2

24. Collins KK. The spectrum of long-term electrophysiologic abnormalities in patients with univentricular hearts. Congenit Heart Dis 2009; 4: 310-317. doi: 10.1111/j.1747-0803.2009.00325.x

25. Wilson TG, lyengar AJ, Winlaw DS, et al. Use of ACE inhibitors in Fontan: Rational or irrational? Int J Cardiol 2016; 210: 95-99. doi: 10.1016/j.ijcard.2016.02.089

26. Bowater SE, Weaver RA, Thorne SA, Clift PF. The safety and effects of bosentan in patients with a Fontan circulation. Congenit Heart Dis 2012; 7: 243-249. doi: 10.1111/j.1747-0803.2012.00635.x

27. Reinhardt $Z$, Uzun $O$, Bhole $V$, et al. Sildenafil in the management of the failing Fontan circulation. Cardiol Young 2010; 20: 522-525. doi: $10.1017 / \mathrm{S} 1047951110000648$

28. Mitchell MB, Campbell DN, Ivy D, et al. Evidence of pulmonary vascular disease after heart transplantation for Fontan circulation failure. J Thorac Cardiovasc Surg 2004; 128: 693-702. doi: 10.1016/j.jtcvs.2004.07.013 29. Michielon G, Parisi F, Squitieri C, et al. Orthotopic heart transplantation for congenital heart disease: an alternative for high-risk fontan candidates? Circulation 2003; 108(Suppl 1): II140-149. doi: 10.1016/S10107940(03)00342-7

30. Lund LH, Edwards LB, Kucheryavaya AY, et al. The registry of the International Society for Heart and Lung Transplantation: thirty-first official adult heart transplant report - 2014; focus theme: retransplantation. J Heart Lung Transplant 2014; 33: 996-1008. doi: 10.1016/j.healun.2014.08.003

31. Pundi KN, Johnson JN, Dearani JA, et al. 40-Year Follow-Up After the Fontan Operation: Long-Term Outcomes of 1,052 Patients. J Am Coll Cardiol 2015; 66: 1700-1710. doi: 10.1016/j.jacc.2015.07.065

32. Chungsomprasong P, Soongswang J, Nana A, et al. Medium and long term outcomes of Fontan operation. J Med Assoc Thai 2011; 94: 323-330. 